\title{
Local Government Reform in South Africa: The Quest for Review and Repositioning of Municipal Administration
}

\author{
O.S. Madumo ${ }^{1, *}$ and S.B. Koma ${ }^{2}$ \\ ${ }^{1}$ School of Public Management and Administration, University of Pretoria, South Africa \\ ${ }^{2}$ Milpark Education, South Africa
}

\begin{abstract}
The endemic municipal governance problems experienced since the dawn of the democratic dispensation manifested through the constant dysfunctional state of municipalities, poor financial performance and poor political leadership clearly necessitate that the national government should revisit and review the constitutional powers granted to the sphere of local government and contemplate introducing a pragmatic model of running municipal affairs. This paper argues that there is a need to review and reposition the model of local government in order to ensure that municipalities appropriately fulfil their constitutional obligations. The existing research pointed to the relevance of the application and utilisation of the different categories of municipalities, thereby enabling the effective delivery of services to communities.

Therefore, the review will amongst others, entail the critical examination of the interventions spearheaded by the national government namely, the Project Consolidate; Municipal Turnaround Strategy/Municipal Infrastructure Support Agent; Operation Clean Audits-2014 and the recently launched Back-to-Basics approach. Based on literature and document reviews this article concludes that the abovementioned interventions have not yielded the desired results yet, if the current performance of municipalities such as Madibeng, Maquasi-Hills, Lekwa-Teemane, Randfontein, Thaba Chweu, Bushbuckridge and Mtubatuba is anything to go by. The outcomes point to the urgent need for a review of the current model of local government that is utilised within a developing society, which is mired with many developmental challenges. This is relevant because South Africa aims at becoming a capable and developmental state as encapsulated in the NDP (National Development Plan) 2030 and for it to achieve such, municipalities are a critical enabler since they operate at the grassroots level.
\end{abstract}

Keywords: Municipal governance, municipal councils, effective administration, performance of municipalities, professionalised local government.

\section{INTRODUCTION}

A municipality is a basic unit of government sphere responsible for the provision of basic services to its residents. Thus, municipalities play an imperative role in improving the quality of life of the inhabitants. Local government is an instrumental layer of government with a physical layout that enables a closer interaction between the government and its people. Thus, through its evolution since democratisation, local government sphere has been plagued with various challenges that threaten development within communities.

This article intends at establishing the legislative framework deemed imperative for an effective and efficient municipal system that will enable the national and provincial government to adequately provide the support to the ailing municipalities. Thus, the research begs the question: "To what extent is the legislative framework utilised as a mechanism to allow for other spheres of government to intervene in the affairs of local government with the aim of ensuring the necessary support in the quest to improve municipal governance? Legislative framework involve legal

*Address correspondence to this author at the School of Public Management and Administration, University of Pretoria, South Africa; Tel: +27 (0) 12420 5736; Fax: +27 (0) 12362 5265; E-mail: onkgopotse.madumo@up.ac.za prescripts governing the operations, governance and administration of municipalities.

In order to answer this question the following subquestions need to be addressed:

- What is known theoretically about the effect of the legislative authority on local governance?

- What is the role of the legislative authority in the theoretical explanation of failing service delivery in local government?

- What do examples from the South African context reveal in this regard?

- What does this tell about the main research question?

Through document analysis, the municipal intervention initiatives are assessed to determine their influence on the current model of local government. First, the discussion will highlight the constitutional mandate of municipalities. The second aspect will be to explore the role of the legislative authority and the current situation within which municipalities finds themselves, in relation to the provision of services. This is triggered by the sporadic protests, under the guise of poor service delivery that some South African municipalities have experienced in recent years. 
Thirdly, the lessons regarding service delivery will be drawn and a discussion on the developmental challenges in South Africa will be initiated. Ultimately, this research is useful since it provides the proposed solutions in the quest to improve effectiveness in the governance structure of the local government system especially developing countries. Thus, the contribution of this article will add to the discourse on the role of local government in enabling the improvement of the living conditions of particularly poor communities in developing countries.

\section{CONSTITUTIONAL MANDATE FOR THE MUNICIPALITIES}

Prior to discussing the constitutional obligations given to municipalities, it is imperative to establish a common definition of the term municipality, for the purposes of avoiding ambiguities in the discussions in this paper. A municipality could be defined as a basic unit of government charged with the responsibility of facilitating an interaction between the government and its people while ensuring the provision of services within an area of jurisdiction (Madumo 2017:55). Thus, South Africa is a constitutional democracy, which implies that municipalities are bound to fulfil responsibilities imposed by the Constitution, 1996.

Democratisation introduced in 1994, brought about tremendous legal order and constitutional status for the sphere of local government. The Constitution of the Republic of South Africa, 1996, assumed its role as the supreme law of the country. Chapter 7 of the Constitution, 1996 recognises local government as one of the three spheres of government. The provisions made in this regard establish the local government as the sphere of government that consist of municipalities, which are responsible for;

- $\quad$ providing the executive and legislative authority of a municipality through the municipal councils;

- $\quad$ ensuring the guaranteed right to govern, on its own initiatives, the local government matters of its community, subject to the legislation passed by the national and provincial legislatures; and

- $\quad$ ensuring the right to apply its powers or ability to execute its functions without any impediment or compromise from another sphere of government.

Furthermore, the importance of the local government sphere is addressed by Section 152 of the Constitution, which accentuates the objectives of the sphere of local government. These are the objects, which municipalities should aim to uphold in providing efficient delivery of services to the local communities within their jurisdiction. The local sphere of government, through municipalities has the responsibility to (Section 152(1) of the Constitution, 1996):

- $\quad$ provide a government that is democratic and accountable;

- deliver services to communities in ways that ensures sustainability;

- $\quad$ stimulate socio-economic development;

- $\quad$ establish an environment that promotes health and safety; and

- encourage community participation in local government affairs.

Emphatically, the Constitution, 1996 states that municipalities should attempt to achieve the abovementioned objectives taking into account their financial and administrative capacity. Therefore, a municipality should give priority to the basic needs of the community by structuring and managing its administration, budgeting and planning processes. This is imperative, since members of the communities should be involved in decision-making processes of the municipality. For instance, it is a prerequisite for municipal council to consider the views of the communities before adopting the municipal planning framework and approving the budget of the municipality.

The South African intergovernmental relations has been arranged in such a way that it allows for the effective and efficient delivery of services by each sphere which is strategically placed to provide such a service. This implies that South Africa utilises the principle of subsidiarity. This is where the political system allows for the decentralisation of decisionmaking to peripheral structures apportioned those powers to effectively function. Thus, each sphere of government will have its responsibility and particularly, the mandate of the local government sphere is carried out by all the 257 municipalities across the entire territory of the Republic. These municipalities exist in various forms, types and categories.

\subsection{Categories of Municipalities}

Municipalities could be established in a variety of ways to perform their duties in the most effective 
manner. Thus, section 155(1) of the Constitution describes the three different categories of municipalities. They are namely:

- Category A: "Category A municipality is described as a municipality that has exclusive executive and legislative authority in its jurisdiction". This implies that, there is only one municipal council in such a municipal area. Such municipalities have a high population density with flourishing economic state and are situated within urban centres. There are eight such municipalities in South Africa.

- Category B: "Category B municipality is a municipality that shares municipal executive and legislative authority in its area with a Category C municipality within whose area it falls". These are rural and semi-urban areas often with a single central business district and low population density. Since the local government elections in 2016, there are 205 local municipalities.

- $\quad$ Category C: "Category C municipality refers to a municipality that has municipal legislative and executive authority in an area that has more than one local municipality". This implies a district municipality, which is established within the boundaries of numerous local municipalities. These municipalities mostly found in rural and semi-urban areas.

These different categories are essential in establishing municipalities within the entire territory of the republic. Thus, each one of the categories should have its own municipal council, which is empowered with the executive and legislative authority over its municipal jurisdiction. Therefore, any type of the executive system, i.e. mayoral, collective and plenary executive, could establish the executive of the municipality in any of the three categories. However, this depends on the physical size of the municipality.

\subsection{Types of Executive Systems Applicable in Municipalities}

There are five types of municipal executive systems established by the national legislation. Section 7 of the Municipal Structures Act, 117 of 1998 establishes the types of executive systems as, "collective executive system, mayoral executive system, plenary executive system, subcouncil participatory system and ward participatory system". Either one or a combination of these executive systems may be applied in any of the categories of municipalities discussed in paragraph 2.1 above. The application of the different types of municipalities takes into account the variation and peculiarity of municipal councils and the need to exercise their constitutional and legislative obligations in the most effective, efficient and responsive manner (Pycroft, 1999:188-189).

This is significant as the executive functioning of the municipality is primarily dependent on the system of governance the municipality employs. Thus, particular circumstances would allow for some flexibility in the establishment of the various types of municipality which should enable effectiveness and efficiency in the functioning of the municipality. Consequently, there is no standard or uniform way to organise all municipal councils, as the physical outlay, resources and political ideology differ from one municipality to the next. Essentially, the significance of establishing different types of municipalities is informed by the view that it affords each member of the provincial executive council (MEC) responsible for local government in a respective province the flexibility to consider and determine the most cost effective, feasible and workable form of local government based on the local socio-economic conditions, basic service delivery challenges, expectations and political preferences (Pycroft, 1998:188-189).

The type of the executive system (i.e. executive mayor, collective executive, plenary executive, ward participatory or sub council participatory) had only a limited impact on these fundamental financial and administrative elements. Consequently, introducing dissimilar types of executive system in municipalities within the same province, and various provinces, gave rise to complexity and confusion that could negate the efforts to enhance public participation in the affairs of local government (Pycroft, 1999:188-189).

\section{CURRENT STATE OF LOCAL GOVERNMENT}

The performance of municipalities throughout the country continues to illustrate large deficiencies and inadequacies in terms of fulfilling their constitutional and legislative obligations (Auditor-General 2018). For example, only $13 \%$ of the municipalities obtained clean audits in the 2016/2017 financial year (Auditor General Report 2017. Furthermore, most local municipalities, especially in KwaZulu Natal, North-West and Mpumalanga provinces, are presently managed by administrators appointed by provincial governments due to their failure to fulfil their constitutional obligations 
in accordance with Section 152 of the Constitution, 1996. Such an intervention was executed through applying Section 139 of the Constitution, 1996. It is within this context that a crucial debate on the functionality of local government sphere has taken a centre stage in the recent past.

The South African sphere of local government is faced with endemic and systemic challenges relating to fulfilment of their constitutional obligations. In 2009, the Ministry of Co-operative Governance and Traditional Affairs (COGTA) undertook a comprehensive diagnosis investigation that resulted into a publication of a report titled "The State of Local Government in South Africa". This report flagged key findings covering governance, service delivery, and policy implementation aspects. The key problems contained in the report pertains to enormous service delivery and backlog challenges, poor communication and lack of accountability relationships with communities, paralysed politicaladministrative interface, blatant corruption and fraud, inadequate internal controls and financial governance, community unrest and protests, weak civil society organisations and inadequate institutional capacity resulting from dearth of technical skills (COGTA Report:2009).

According to Madumo (2012:50) the critical challenges facing municipalities, include corruption, maladministration, and political instability, lack of administrative capacity and lack of adequate financial control systems. According to the 2012-2013 AuditorGeneral (2014:59) the possession of proper skills, experience and adequate capacity by key officials, namely; the municipal manager, chief financial officer and senior managers, are imperative to ensure excellent audit outcomes and exceptional service delivery in municipalities. The lack of adequate capacity to perform some functions is detrimental to the development of municipalities, and subsequently it affects the municipalities' ability to deliver on their constitutional obligation and mandate (South African Institute of Race Relations n.d.:16)

\subsection{Governing Responsibilities of Municipal Councils}

The governance framework within which municipalities operate is cogently stipulated in the Constitution, 1996 and the Local Government: Municipal Systems Act, 32 of 2000. Governance entail the constitutional, legal and administrative parameters by which a governing body ought to exercise its power, including checks and balances mechanisms set up to ensure accountability, rule of law, transparency and public participation. Within a municipality, governance involves the manner in which political office-bearers and officials steer municipalities to respond to the demands, and expectations of the affected communities.

Their role is to ensure that local government meets its constitutional obligations, within the limits of the resources at its disposal, and utilise these resources economically, effectively and efficiently to improve the quality of life of communities. The core functions of a municipal council include planning, decision-making and legislative oversight. Arguably, in order for a municipality to deliver public services effectively and efficiently to communities, its municipal council should exercise sound business judgment within its assigned fiduciary powers and functions (Madumo 2017:99).

A municipal council duly serves as a governing body of a municipality vested with both the executive and legislative authority in an area of jurisdiction. This implies an elected body of public representatives constituting the final decision-making authority of a municipality (Madumo 2017:31). Thus, the council is responsible for formulating the municipality's mission, policy and administration parameters and for approving the integrated development plan (IDP) and municipal budget. In exercising its statutory functions, the municipal council may delegate some of its executive functions to an executive mayor or an executive committee, depending on which type of executive system is being applied in a particular municipality in terms of the prescribed legislation.

The executive mayor or executive committee is expected to articulate the vision and policy direction of the municipality; oversee and monitor the implementation of policy, service delivery strategies and programmes; and take responsibility for municipal council decisions. Therefore, the executive mayor is a key link between the municipality and its communities and must provide political guidance and direction on service delivery planning and budgeting. An executive mayor is empowered to review and evaluate the needs of the community, as well as to recommend feasible and realistic strategies, initiatives and services to address priority needs through a municipal budget and its accompanying integrated planning framework of the municipality in accordance with the legislation.

The municipal manager as the head of administration plays a significant role of providing an 
operational direction to the municipal council. Thus, as the accounting officer of a municipality, the municipal manager advises the executive mayor or executive committee and council on administrative matters relating to policy, finances, personnel and organisational issues that a municipality needs to execute and fulfil its constitutional and legislative mandates. The advisory role entails assisting the municipal council to interpret its constitutional duties. Furthermore, the municipal manager executes the municipal council's mission and policies and must manage the affairs of a municipality in the most effective and efficient manner.

Section 19(1) of the Local Government: Municipal Structures Act, 117 of 1998, stipulates that "a municipal council must strive within its capacity to achieve the objects set out in Section 152 of the Constitution, 1996". Furthermore, section 19(2) of the Municipal Structures Act, 1998 prescribes that a municipal council must annually review: the needs of the community; its priorities to meet those needs; its institutional processes and mechanisms for involving the community in local government affairs; its organisational and internal or external delivery mechanisms for meeting the needs of the community; and its overall performance in achieving the objectives of the municipal council.

In addition, section 73 of the Local Government: Municipal Systems Act 32 of 2000 provides for the municipality to implement the obligations enshrined in the Constitution, which expects them to prioritise the necessary basic needs of the local communities and promoting progress within their respective communities.

These legislative provisions are aimed at ensuring that municipalities are development oriented in the manner in which they operate, plan, allocate and manage resources and fulfil their constitutional obligations.

\subsection{Local Government Performance: Issues and Options}

The discourse on the role and existence of the local sphere of government is premised on four crucial points. The first point is that local government is currently faced with enormous institutional capacity deficiencies glaring in most municipalities, including, but not limited to, the following:
- $\quad$ limited and shortage of professional skilled staff especially in the areas of engineering, electricity and environmental health;

- blatant transgressions of law governing municipalities;

- $\quad$ bad management of municipal assets;

- non-existence of internal controls and lack of consequences management; and

- inability of municipalities to collect revenue due to them and the high debt owed to Eskom attest to this point (Ababio 2007; Maserumule 2008; Koma 2010;Auditor-General 2017).

Secondly, the complexity of the operation of local and district municipalities cause duplication and role conflict in the provision of municipal and public services. Thus, there is a variation of capacity levels between these two differently formed municipalities in certain provinces and it would be advisable that a single tier of municipalities is established to remedy this situation. Consequently, a single-tier municipality could operate as a sole authority responsible for the provision of bulk services, such as water reticulation and bulk electricity infrastructure.

Equally, where the capacity of local municipalities is weak, therefore, the district municipality should continue to assume a technical supporting role and help provide bulk services on behalf of these municipalities and develop and strengthen capacity and share best practices.

The third point is the issue of decentralisation of functions between the provinces and local sphere of government. Both the schedules 4 and 5 (part B) clearly outlines the areas of functional competence performed by the various spheres of government. Until recently, the Gauteng Provincial Government has decentralised the housing function to the City of Johannesburg after the provincial department of human settlements completed a thorough readiness audit. However, most provinces are reluctant to decentralise some of their functions to the local municipalities. Furthermore, some provinces are also reluctant to decentralise functions, powers and funding to municipalities, thereby rendering provinces to be perceived as an obstruction to development and facilitation of public service delivery.

Fourthly, both the national and provincial governments should promote a professionalised local 
government, thereby creating an environment conducive for career development in local government. The decisive step undertaken by the Minister of Cogta Dr. Zweli Mkhize in May 2018 in collaborating with the Engineering Council of South Africa and the South African Association of Professional Consulting Planners with the purpose of beefing up engineering and planning capacity of selected municipalities is worth commending. This intervention will help municipalities to develop proper technical and infrastructure plan, capital budgets and further be able to spend the Municipal Infrastructure Grants (MIG) devoted to improve service delivery provisioning. More significantly, municipalities would be able to serve as employers of choice, thus, attract, and retain professionally skilled and qualified engineers and city and town planners in the short, medium and long term.

The local government sphere is not entirely inefficient as there are also notable pockets of excellence as illustrated by some municipalities in respect to their legislative obligations. Examples of such municipalities are reflected in Table 1 below:

It is noteworthy that the Ministry of Co-operative Governance and Traditional Affairs had previously initiated a number of projects in the quest to improve the service delivery systems within municipalities. These initiatives are, namely; Operation Clean Audits 2014, the Local Government Turnaround Strategy 2011 and Back-to-Basics strategy. Consequently, the propulsion of these interventions clearly demonstrates the motivation that drives the authorities in ensuring an improvement of local government in line with the legislative mandate, service delivery imperatives, and governance and management that oversees the performance of municipalities. However, the efficacy of these interventions has been disappointing in many respects. In 2014, the Department of Cooperative Governance (DCoG) launched the Local Government Back to Basics Approach centred on five pillars namely, public participation; financial management; good governance; institutional capacity and infrastructure services. The thrust of this approach is to build effective, efficient and viable municipalities that prioritises the concerns and demands of local communities, create sufficient avenues for citizens involvement in the affairs of local government, providing state-of-the-art public infrastructure underpinned by quality standards and excellence; ensuring good governance in the areas of municipal finance and developing capable administrative machinery tailored for responsive public service delivery. The success of this approach hinges on bold and decisive political and executive leadership within the senior echelons of municipalities and adequate provisioning of resources in order to ensure that municipalities best respond to the needs of local communities in the most efficient and effective manner.

\subsubsection{Lessons from the Venda Building Society (VBS) Scandal}

The findings of the forensic investigation into the governance of the VBS informed by the irregular and unlawful investments made by some municipalities situated in the provinces of Limpopo, North-West, Gauteng and Mpumalanga contained in a report titled

Table 1: Areas of Performance for Some Municipalities

\begin{tabular}{|c|c|c|c|}
\hline Province & Municipality & Area of performance & Reasons \\
\hline Northern Cape & $\begin{array}{l}\text { Gamagara Local } \\
\text { municipality }\end{array}$ & Provision of Service delivery & $\begin{array}{c}\text { Backlogs have been eradicated } \\
\text { Established a strong economic centre }\end{array}$ \\
\hline Western Cape & Overstrand & Ensuring financial viability & $\begin{array}{l}\text { Maintained a good credit rating } \\
\text { Have an outstanding rates and tax collection } \\
\text { turnaround time } \\
\text { Maintaining a good Capital Expenditure }\end{array}$ \\
\hline Limpopo & Thabazimbi & $\begin{array}{c}\text { Promoting the local economic } \\
\text { development }\end{array}$ & $\begin{array}{l}\text { Maintained strong economic sectors } \\
\text { Promotion of good management practices with } \\
\text { the business sector }\end{array}$ \\
\hline Western Cape & Cape Winelands & Facilitating planning & $\begin{array}{l}\text { Facilitate economic growth in its area } \\
\text { Outstanding approach to Integrated } \\
\text { Development Planning process }\end{array}$ \\
\hline Gauteng & $\begin{array}{l}\text { West Rand District } \\
\text { municipality }\end{array}$ & Ensuring good governance & Enhancing the democratic development \\
\hline
\end{tabular}

Source: COGTA Report, 2009. 
"The Great Bank Heist" points to an array of crucial issues as far as the capacity of Municipal Councils and Executive Mayors/Mayors is concerned. Suffice it to say that the investigations were carried out as a result of the collapse of the VBS that led to its liquidation in March 2018. The South African Reserve Bank sanctioned this investigation. The issues may be surmised as follows:

- Weak Municipal Councils in terms of exercising oversight role over the executive mayors;

- Weak Municipal Public Accounts (MPACs) in exercising oversight role over the financial governance and internal controls of municipalities;

- Poor political leadership at the level of Executive Mayors and Mayoral Executive Committees;

- Poor executive leadership by Municipal Managers and Chief Finance Officers;

- Poor professional ethical conduct on the part of the Political Office-bearers and senior municipal executives;

- $\quad$ Poor advisory role by the municipal managers and chief finance officers;

- Deliberate disregard of the law specifically the Municipal Finance Management Act by both the political office-bearers and municipal executives; and

- Glaring financial misconduct displayed by all the municipal officials involved in this scandal.

It should be pointed out that Municipal Councils are legally empowered to act decisively against executive mayors/mayors and officials through various means such as removal, suspensions and dismissals. Municipal Councils may not abdicate this responsibility to any other party. The effective execution of this role and the assertiveness needed on the part of Municipal Councils will go a long way in realising the significant constitutional values of building accountable, efficient, effective and responsive public administration for the benefit of communities.

This scandal is also a setback to the Back-to-Basics approach, which in part primarily targets the promotion of good governance and proper management of finances in municipalities. More significantly, the obligation imposed on municipalities to guarantee the provision of basic services to communities in a sustainable manner in accordance with section 152 of the Constitution, 1996 has regrettably been affected by the unlawful investment decisions made by the political office-bearers and municipal managers governing these municipalities.

\subsubsection{Illegal Appointment of Municipal Managers}

The municipal councils of both Nkandla local municipality and Mthonjaneni local municipality in KwaZulu-Natal Province were found by the Pietermaritzburg High Court to have illegally appointed their municipal managers. This came after the respective councils contravened section $54 \mathrm{~A}(3)$ of the Municipal Systems Act, 2000 which sets out the minimum prerequisites for appointing a municipal manager. Neither of the two candidates had the minimum of five years' work experience at a senior management position. Despite this, the Nkandla local municipal council, seeks to appeal the ruling of the High Court and further advised their municipal manager to remain in office until the appeal application has been lodged with the judicial authority (SA Local Government Research Centre 2019:10-11). In this case, it is clear that the municipal council has taken a decision without properly considering the full extent of the legislation. This could be as a result of the political nature of the decision taken of appointing an accounting officer on partisan basis. This explains why some municipal managers would at times make decisions that are of greater interest to the partisan interest of the governing party in a municipality and not to the greater benefit of the communities, they ought to serve.

The process of decision-making in a political environment is multifaceted as it often addresses specific interests, rather than fulfilling the general needs of communities (Riemer, Simon and Romance 2006:320). Thus the process of decision-making within this milieu does not always consider the best possible alternative. Since the municipal councils are generally political in their character, the effect of political power on the decision-makers could be dominant in such a way that the decision-making process purely becomes a formality to only achieve political goals.

The court case instigated by Vuyo Mlokoti $v$ Amathole District Municipality and Mlamli Zenzile clearly illustrated this point. In this case the Court concluded that the municipal council unlawfully appointed Mlamli Zenzile as the municipal manager after being politically influenced by Regional Executive Committee (REC) of the governing party in that 
municipality (African National Congress), through its political caucus. This is regardless of the fact that Vuyo Mlokoti outperformed Mlamli Zenzile as determined by the interviewing panel, where they scored Mlokoti as the best candidate and Zenzile as the second best (Madumo 2017:106-107).

Consequently, the municipal council endorsed a caucus decision by appointing Mlamli Zenzile. The High Court made a determination that this decision was unlawful and must be reversed by appointing Vuyo Mlokoti as the accounting officer (municipal manager) in Amathole (Eastern Cape High Court Judgement Case number: 1428/2008 2008).

From these experiences of appointment of municipal managers, it could be deduced that, municipal councils often consider political expediency when making a decision on the appointment of an accounting officer. In both the cases of the two KwaZulu-Natal municipalities and Vuyo Mlokoti vs Amathole District and Mlamli Zenzile, it is clear that the respective councils disregarded various other elements when they decided to appoint their respective municipal managers.

\subsection{Municipal Administration}

According Section 151(2) of the Constitution, 1996 and in line with Section 11(1) of the Local Government: Municipal Systems Act (Act No. 32 of 2000), the executive and legislative authority of a municipality are a direct responsibility of the council of the municipality. Section 151(3) of the Constitution makes a provision for a municipality to have the right to govern, on its own initiative, the local government affairs of its community, subject to national and provincial legislation, as provided for in the Constitution, 1996.

Furthermore, section 151(4) makes a provision for the national or a provincial government to avoid compromising or impeding a municipality's ability or right to exercise its power or perform its functions. A municipal manager who is also the accounting officer in line with the Municipal Systems Act, 2000 as amended, heads the administration of each municipality.

The municipal manager is personally held liable by the council for the usage of the finances of the departments in a municipality. Since 2011, municipalities have not been able to fully appoint municipal managers in their positions. Instead, 83 municipal managers in 2011, were serving in their positions in an acting capacity. This translates to about
$30 \%$ of the municipal managers appointed in the acting capacity in this critical position. The notion of appointing the head of administration in an acting capacity, has a potential to deter him/her to challenge some of the detriment decisions by the municipal council and tends to be easily influenced, thereby interrupting the delivery of services in a specific municipality.

This could be as a result of an attempt to impress the council with the expectation that he/she will be fully appointed for a full five years as stipulated in the legislation. Municipalities in all the provinces are affected by this phenomenon, as the issue at times could be propelled by the lack of appropriate skills required for such a senior position. In 2012, about $30 \%$ of the municipalities across the country had appointed their municipal managers in acting capacity (Madumo 2012:51). Sometimes officials appointed in such key positions do not meet all the necessary requirements. Thirty municipal managers did not possess the required educational qualification, whereas 65 of the municipal managers either did not meet or only met some of the prescribed competency requirements (Auditor-General 2014:60).

According to the Local Government Back to Basics Approach (2014:7) the staffing of municipal administrations should be assessed on the basis of the following targets:

- $\quad$ Ensuring that the top/senior posts (i.e. Municipal Manager, Finance, Infrastructure, Corporate Services, Community development and Development Planning) are occupied by persons who have the necessary competence and qualifications. These individuals should be in possession of the minimum competency levels prescribed in terms of the relevant municipal legislation.

- Ensuring that the municipal organisational structures are underlined by realistic and resourced service delivery model.

- $\quad$ Ensuring that there is provision of continuous human resource development and capacity building interventions.

\section{PROFESSIONALISING LOCAL GOVERNMENT}

The quest to professionalise local government was also given an impetus by the imposition of constraints of political rights of senior managers within 
municipalities in terms of the Municipal Systems Amendment Act No. 7 of 2011. This legislation stipulates that a municipal manager or manager directly accountable to a municipal manager may not hold political office in a political party whether in a permanent, temporary or acting capacity. This amended provision of the Municipal Systems Act would help resolve the perennial governance problem stemming from the political-administrative relationship between the political office-bearers who happen to hold political office of the governing party and the senior municipal officials within the context of a municipality that invariably borders on interference in the day to day running of municipal affairs. However, this piece of legislation has been declared invalid by the Constitutional Court, where it argued that the procedure followed by Parliament in passing this legislation was flawed.

From the foregoing, it is clear that municipalities require structured, focussed and nationally driven support and intervention. The endemic municipal governance problems experienced since the dawn of the democratic dispensation manifested through the constant dysfunctional state of municipalities, poor financial performance and poor political leadership clearly necessitate that the national government should revisit and review the constitutional powers granted to the sphere of local government and contemplate introducing a pragmatic model of running municipal affairs.

This model may entail changing the Constitution so as to allow the national government to directly intervene in the affairs of municipalities and thereby ensuring that the municipal political and administrative executives are held accountable for the dysfunctional state of their municipalities to the national government; the salaries and benefits of councillors are catered specifically through the national fiscus in unison with both the national and provincial legislative authorities and thus releasing municipal coffers from this burden in order to provide sustainable municipal basic services (for example majority of municipalities are 100 percent reliant on conditional grants and therefore, a bigger chunk of the funds is directed to salaries and benefits of municipal personnel and political office-bearers).

\section{CONCLUSION}

The premise of this article was intended to spark a discussion on the review and repositioning of local government model with a view to ensure that municipalities appropriately fulfil their constitutional obligations. The article explored a discussion on the constitutional mandate for the municipalities. Furthermore, the role of the legislative authority as an enabler to ensure municipal service provision was emphasised. This was meant to examine the developmental challenges encountering local government, which are often noticeable through the sporadic protests.

A South African case was investigated, in an effort to establish similar characteristics that are mostly noticeable in developing countries. This was important for the research, since its focus is on ensuring the improvement of the living conditions of residents within the local government environment. The research revealed that the legislative framework plays a significant role in influencing the governance of the municipalities regarding their service provision responsibilities. Furthermore, the article elucidated on the state of institutional and political reforms shaping the local sphere of government.

\section{REFERENCES}

Ababio E. 2007. Bloodhounds by municipal financial management: what goes awry? Journal of Public Administration. Conference proceedings. Vol 42(5) 3-14.

Auditor-General. 2014. Auditor-General of South Africa: Consolidated general report on the audit outcomes of local government, 2012-2013.

Auditor-General. 2017. Auditor-General of South Africa: Consolidated general report on the audit outcomes of local government, 2016-2017.

Department of Co-operative Governance and Traditional Affairs. 2009. Report on the State of Local Government in South Africa: Pretoria.

Eastern Cape High Court Judgement. 2008. High Court judgement in the matter between Vuyo Mlokoti against Amathole District Municipality and Mlamli Zenzile. Case number 1428/2008. Eastern Cape High Court.

Koma SB. 2010. The state of local government in South Africa: Issues, trends and options. Journal of Public Administration vol 45(1) 111-120.

Madumo, O.S. 2012. The promotion of developmental local government to facilitate a developmental state. Administratio Publica. 20(3):40-54.

Madumo, O.S. 2017. An evaluation of the functioning of metropolitan municipal councils in Gauteng, South Africa. DAdmin thesis. University of Pretoria.

Maserumule MH. 2008. Framework for strengthening the capacity of municipalities in South African: A developmental local government perspective. Journal of Public Administration. Vol. 3(43) 436-451.

National Development Plan. 2012. The Presidency. Pretoria.

Pycroft, C. 1999. Restructuring Non-Metropolitan Local Government in South Africa. Public Administration and Development 19:179-192.

https://doi.org/10.1002/(SICI)1099162X(199905)19:2<179::AID-PAD61>3.0.CO;2-6 
Riemer, N., Simon, D.W. \& Romance, J. 2006. The challenge of politics: an introduction to political science. $2^{\text {nd }}$ edition. Washington: CQ Press.

Republic of South Africa. 1996. Constitution, 1996.

Republic of South Africa. 2014. Local Government Back to Basics Approach. Ministry of Cooperative Governance. Pretoria.

Republic of South Africa. 2000. Local Government: Municipal Systems Act, 2000 (Act 32 of 2000). Pretoria: Government Printer.
SA Local Government Research Centre. 2012. The SA Local Government Briefing. January issue. Cape Town: SA Local Government Research Centre.

SA Local Government Research Centre. 2019. The South African Local Government Briefing. February issue. Cape Town: SA Local Government Research Centre.

South African Institute of Race Relations. N.d. The 80/20 report: local government in 80 indicators after 20 years of democracy. South African Institute of Race Relations

Received on 30-04-2019

Accepted on 01-06-2019

Published on 07-08-2019

DOI: https://doi.org/10.6000/1929-7092.2019.08.50

(C) 2019 Madumo and Koma; Licensee Lifescience Global.

This is an open access article licensed under the terms of the Creative Commons Attribution Non-Commercial License (http://creativecommons.org/licenses/by-nc/3.0/) which permits unrestricted, non-commercial use, distribution and reproduction in any medium, provided the work is properly cited. 